\title{
The importance of NFKB1 rs4648068 and RUNX2 rs7771980 polymorphisms in bone metabolism of postmenopausal Polish women
}

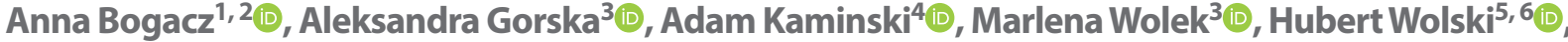

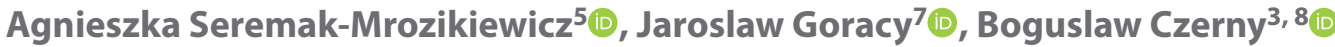 \\ ${ }^{1}$ Department of Pharmacology and Phytochemistry, Institute of Natural Fibers and Medicinal Plants, Poznan, Poland \\ ${ }^{2}$ Department of Histocompatibility with Laboratory of Genetic Diagnostics, Regional Blood Center, Poznan, Poland \\ ${ }^{3}$ Department of Stem Cells and Regenerative Medicine, Institute of Natural Fibres and Medicinal Plants, Poznan, Poland \\ ${ }^{4}$ Clinic of Pediatric Orthopedics, Pomeranian Medical University, Szczecin, Poland \\ ${ }^{5}$ Division of Perinatology and Women's Diseases, Poznan University of Medical Sciences, Poznan, Poland \\ ${ }^{6}$ Division of Gynecology and Obstetrics, Podhale Multidisciplinary Hospital, Nowy Targ, Poland \\ 7 Independent Laboratory of Invasive Cardiology, Pomeranian Medical University in Szczecin, Poland \\ ${ }^{8}$ Department of Pharmacology and Pharmacoeconomics, Pomeranian Medical University in Szczecin, Poland
}

\begin{abstract}
Objectives: Osteoporosis is a multifactorial disease that causes a loss of bone density. However, genetic factors play an increasingly important role in its development. To thoroughly understand the molecular mechanisms, polymorphic variants of genes candidate for osteoporosis are still being sought. The aim of our study was to investigate the influence of $N F K B 1$ gene rs4648068 $(A>G)$ and RUNX2 gene rs7771980 $(-1025 T>C)$ polymorphisms on the risk of osteoporosis.

Material and methods: A group of 675 postmenopausal Caucasian women (109 women with osteopenia, 333 with osteoporosis and 233 with normal T-score) were examined. The bone mineral density (BMD) at the lumbar spine (L1-L4) was measured by dual energy $x$-ray absorptiometry (DXA). The analysis of NFKB1 and RUNX2 polymorphisms was performed using real-time PCR method.

Results: Analysis of NFKB1 gene rs 4648068 polymorphism showed that the GG genotype was slightly more frequent in the study groups compared to the control group. In the osteoporosis group, patients with the $G$ allele in the genotype have lower bone mineral density values. For the RUNX2 rs7771980 polymorphism, in women with osteopenia we observed an increased incidence of TC heterozygotes compared to the control group ( $29.40 \%$ vs $24.90 \%, p>0.05$ ), and in women with osteoporosis, the TT genotype was more common ( $78.70 \%$ vs $73.80 \%, p>0.05)$. No correlation was observed between the genotypes and the clinical parameters.

Conclusions: The analysis showed no significant relationship between the genotypic distribution and the individual clinical parameters. However, it is suggested an association between the rs 4648068 polymorphism of the NFKB1 gene and an increased risk of developing osteoporosis.
\end{abstract}

Key words: osteoporosis; polymorphism; NFKB1; RUNX2; postmenopausal women

Ginekologia Polska 2021; 92, 9: 617-623

\section{INTRODUCTION}

Osteoporosis is a multifactorial, chronic metabolic disease of the skeletal system. It is characterized by a progressive decrease in bone density (BMD), which leads to an increased risk of fractures [1]. Initially, it develops asymptomatically, there is a painless deterioration of the state of the skeletal system and destruction of bone mass. Osteoporotic fractures, caused as a result of light injuries, are usually the first noticeable symptom, indicating the very advanced disease [2].The occurrence of osteoporosis depends on age, 
race, sex and ethnicity. The incidence increases with age; however, most cases are observed in patients over 70 years of age. Osteoporosis is more common in women, especially in postmenopausal women (postmenopausal osteoporosis). The greatest risk of developing osteoporosis was observed in Caucasian and Asian women [2, 3].

In order to determine the genetic basis for the development of osteoporosis, the single nucleotide polymorphisms involved in bone tissue metabolism, such as receptor activator for nuclear factor $\mathrm{K} B$ (RANK), receptor activator for nuclear factor $\mathrm{K} B$ ligand (RANKL) or other genes affecting ossification, are analyzed [4]. RANKL is a protein found on the surface of osteoblasts that participates in the formation of mature osteoclasts.

It binds RANK, located on the surface of osteoclasts, as a result of which these cells differentiate into mature multinucleated forms. Blocking RANKL prevents its attachment to a receptor that inhibits osteoclast maturation and bone resorption. The effect of the RANK and RANKL interaction is the activation of nuclear factor of activated T cells transcription complex 1 (NFATc1), nuclear factor KB (NFkB) i cellular Finkel-Biskis-Jinkins murine osteosarcoma (cFos/Fra-1) transcription factors. The NF-kB protein family regulates the expression of many genes involved in various immune and inflammatory response processes. It includes five transcription factors NF-KB1 (also named p50), NF-KB2 (or p52), RelA (or p65), RelB and c-Rel [5-7]. It is not known exactly how NFkB affects mature osteoclasts. It has been found in mice that the deletion of the gene encoding the NFkB transcription factor, more specifically the p50 and p52 subunits, is responsible for osteoclast-independent, rare, hereditary disease marbled bone called Albers and Schõnberg disease or osteopetrosis [8, 9].

Another gene involved in bone formation is runt-related transcription factor 2 (RUNX2), located at the 6p21 locus. It contains two promoters $\mathrm{P} 1$ and $\mathrm{P} 2$ and seven exons and encodes two protein isoforms: RUNX2-I and RUNX2-II. It is a key transcription factor associated with osteoblast differentiation, RUNX2-I involved in the early stages of osteoclastgenesis, and RUNX2-II in the process of osteoblast maturation. Studies have shown that mice deficient of the transcription factor RUNX2 did not show complete bone formation, and craniofacial dysplasia (CCD) was observed in knockout heterozygous.

The aim of our study was to check whether selected polymorphisms NFKB1 rs4648068 (A>G) and RUNX2 rs7771980 (-1025T>C) are more common in postmenopausal women and whether they may predispose to the development of osteoporosis.

\section{MATERIAL AND METHODS}

A group of 675 postmenopausal Caucasian women with Polish origin was examined. The patients were di- vided into three groups: 109 women with osteopenia (mean age $53.24 \pm 0.74$ years), 333 with osteoporosis (mean age $56.06 \pm 0.75$ years) and 233 control group with normal T-score (mean age 53.38 \pm 1.01 years). During the interview, information was obtained on illnesses, medications taken, patient's age, reproduction age, number of pregnancies and birth weight, and age of first and last menstruation. Women with ovariectomy and taking medicines which might influence the bone metabolism (hormone therapy, selective modulators of estrogen receptors) as well as women with diseases affecting the density and loss of bone mass were excluded from the study.

Bone mineral density (BMD) measurements were performed at the Densitometry Laboratory, Clinical Hospital No. 1, Pomeranian Medical University in Szczecin, using a densitometric apparatus — LUNAR DPX 100 (Lunar Corp., Madison, USA). Each woman was examined in the lumbar spine from L2 to L4 using DEXA (Dual Energy X-ray Absorptiometry). The study determined BMD, T-score and Z-score parameters, as well as the average BMD YA and AM for young-adult and age-matched. Based on the value of the T-score, women were classified into the group with osteopenia $(-2.5<$ T-score $<-1)$, osteoporosis (T-score $<-2.5$ ) and with the correct T-score - control group (T-score $>-1$ ). The study was approved by Local Bioethical Committee of Pomeranian Medical University in Szczecin.

The genetic analysis was performed at the Department of Stem Cell and Regenerative Medicine, Institute of Natural Fibers and Medicinal Plants, Poznan. Genomic DNA was isolated from the blood using a commercial QIAamp Blood Kit (Qiagen GmbH, Hilden, Germany) according to the protocol. The LightCycler FastStart DNA Master HybProbe (Roche Diagnostics) and LightCycler ${ }^{\circledR} 96$ instruments were used for NFKB1 and RUNX2 genotyping. Determination of the NFKB1 rs464806 polymorphism and the RUNX2 rs7771980 polymorphism was performed using LightSNiP NFKB1 and RUNX2 (TIBMolbiol, Germany). PCR was carried out according to the manufacturer's protocol.

Data analysis was performed using SPSS Statistics 17.0 using one-way ANOVA test. The value of $p<0.05$ was considered as statistically significant.

\section{RESULTS}

The characteristics of clinical parameters of the study groups and the control group in postmenopausal women was showed in Table 1. The differences in the T-score and Z-score values between the groups (osteoporosis T-score: $-3.16 \pm 0.06$, Z-score: $-3.57 \pm 1.95$, osteopenia: T-score: $1.83 \pm 0.04$, Z-score: $0.84 \pm 0.08$, control group: T-score: $0.08 \pm 0.11$, Z-score: $0.64 \pm 0.20$ ) were observed. Studies have shown a correlation between the patients'BMI and individual groups (osteoporosis: $23.79 \pm 0.32$, osteope- 
Table 1. Characteristics of the study population (postmenopausal women with osteopenia, osteoporosis and normal T-score)

\begin{tabular}{|c|c|c|c|c|}
\hline & & \multirow{2}{*}{ Mean \pm SEM } & \multicolumn{2}{|c|}{$95 \% \mathrm{Cl}$} \\
\hline & & & Min & Max \\
\hline \multirow{3}{*}{ T-score } & Osteopenia* & $-1.83 \pm 0.04$ & -1.91 & -1.75 \\
\hline & Osteoporosis & $-3.16 \pm 0.06$ & -3.28 & -3.05 \\
\hline & Controls & $0.08 \pm 0.11$ & -0.15 & 0.30 \\
\hline \multirow{3}{*}{ Z-score } & Osteopenia & $-0.84 \pm 0.08$ & -1.01 & -0.68 \\
\hline & Osteoporosis & $-3.57 \pm 1.95$ & -7.46 & 0.32 \\
\hline & Controls & $0.64 \pm 0.20$ & 0.24 & 1.04 \\
\hline \multirow{3}{*}{$\begin{array}{l}\text { Body mass } \\
{[\mathrm{kg}]}\end{array}$} & Osteopenia* & $65.17 \pm 1.00$ & 63.20 & 67.14 \\
\hline & Osteoporosis & $61.21 \pm 0.94$ & 59.35 & 63.07 \\
\hline & Controls & $68.73 \pm 1.49$ & 65.75 & 71.71 \\
\hline \multirow{3}{*}{$\begin{array}{l}\text { Height } \\
\text { [cm] }\end{array}$} & Osteopenia* & $162.63 \pm 0.45$ & 161.74 & 163.52 \\
\hline & Osteoporosis & $160.25 \pm 0.53$ & 159.20 & 161.30 \\
\hline & Controls & $163.08 \pm 0.74$ & 161.61 & 164.55 \\
\hline \multirow{3}{*}{$\begin{array}{l}\text { BMI } \\
{\left[\mathrm{kg} / \mathrm{m}^{2}\right]}\end{array}$} & Osteopenia* & $24.64 \pm 0.36$ & 23.94 & 25.35 \\
\hline & Osteoporosis & $23.79 \pm 0.32$ & 23.16 & 24.42 \\
\hline & Controls & $25.88 \pm 0.56$ & 24.77 & 26.99 \\
\hline \multirow{3}{*}{$\begin{array}{l}\text { Age } \\
\text { [years] }\end{array}$} & Osteopenia* & $53.24 \pm 0.74$ & 51.78 & 54.69 \\
\hline & Osteoporosis & $56.06 \pm 0.75$ & 54.59 & 57.54 \\
\hline & Controls & $53.38 \pm 1.01$ & 51.36 & 55.40 \\
\hline \multirow{3}{*}{$\begin{array}{l}\text { Birth weight } \\
\text { [g] }\end{array}$} & Osteopenia* & $3226.79 \pm 77.68$ & 3067.39 & 3386.18 \\
\hline & Osteoporosis & $3141.25 \pm 134.08$ & 2855.47 & 3427.03 \\
\hline & Controls & $3628.95 \pm 110.29$ & 3397.23 & 3860.66 \\
\hline \multirow{3}{*}{$\begin{array}{l}\text { Years of } \\
\text { reproduction }\end{array}$} & Osteopenia & $36.20 \pm 0.64$ & 34.93 & 37.47 \\
\hline & Osteoporosis & $35.62 \pm 0.62$ & 34.37 & 36.86 \\
\hline & Controls & $36.38 \pm 0.95$ & 34.45 & 38.30 \\
\hline \multirow{3}{*}{$\begin{array}{l}\text { Age of first } \\
\text { menstruation }\end{array}$} & Osteopenia & $13.12 \pm 0.31$ & 12.50 & 13.74 \\
\hline & Osteoporosis & $12.94 \pm 0.27$ & 12.40 & 13.47 \\
\hline & Controls & $13.38 \pm 0.33$ & 12.70 & 14.05 \\
\hline \multirow{3}{*}{$\begin{array}{l}\text { Age of last } \\
\text { menstruation }\end{array}$} & Osteopenia & $49.21 \pm 0.50$ & 48.22 & 50.20 \\
\hline & Osteoporosis & $48.16 \pm 0.55$ & 47.07 & 49.25 \\
\hline & Controls & $50.17 \pm 0.69$ & 48.79 & 51.56 \\
\hline \multirow{3}{*}{$\begin{array}{l}\text { Number of } \\
\text { pregnancies }\end{array}$} & Osteopenia & $1.89 \pm 0.10$ & 1.69 & 2.08 \\
\hline & Osteoporosis & $1.96 \pm 0.14$ & 1.69 & 2.22 \\
\hline & Controls & $1.94 \pm 0.04$ & 1.64 & 2.24 \\
\hline \multirow{3}{*}{$\begin{array}{l}\text { Years after } \\
\text { menopause }\end{array}$} & Osteopenia* & $7.18 \pm 0.11$ & 5.63 & 8.74 \\
\hline & Osteoporosis & $10.63 \pm 0.08$ & 9.21 & 12.06 \\
\hline & Controls & $7.03 \pm 0.08$ & 5.02 & 9.05 \\
\hline \multirow{3}{*}{$\begin{array}{l}\text { BMD } \\
\mathrm{L2} 2-\mathrm{L} 4\left[\mathrm{~g} / \mathrm{cm}^{2}\right]\end{array}$} & Osteopenia & $0.97 \pm 0.20$ & 0.93 & 1.01 \\
\hline & Osteoporosis & $0.98 \pm 0.81$ & 0.95 & 1.00 \\
\hline & Controls & $0.97 \pm 1.00$ & 0.93 & 1.01 \\
\hline \multirow{3}{*}{$\begin{array}{l}\text { BMD } \\
\text { L2-L4 YA [\%] }\end{array}$} & Osteopenia & $80.90 \pm 1.49$ & 77.49 & 84.32 \\
\hline & Osteoporosis & $81.28 \pm 0.66$ & 78.82 & 83.74 \\
\hline & Controls & $81.02 \pm 0.45$ & 77.46 & 84.59 \\
\hline \multirow{3}{*}{ BMD L2-L4 AM [\%] } & Osteopenia & $89.13 \pm 0.74$ & 85.50 & 92.76 \\
\hline & Osteoporosis & $89.50 \pm 0.32$ & 87.07 & 91.94 \\
\hline & Controls & $89.78 \pm 0.36$ & 85.88 & 93.67 \\
\hline
\end{tabular}

${ }^{*} \mathrm{p}<0.05$ - comparison between the groups with osteopenia/osteoporosis and normal T-score (one-way ANOVA); BMI — body mass index; BMD — bone mineral density 
nia: $24.64 \pm 0.36$ vs control group: $25.88 \pm 0.56, p<0.05$ ). A similar relationship was observed for birth weight (osteoporosis: $3141.25 \pm 134.08 \mathrm{~g}$, osteopenia: $3226.78 \pm 77.68 \mathrm{~g}$ vs control group: $3628.95 \pm 110.29 \mathrm{~g}, \mathrm{p}<0.05)$. Other clinical parameters do not differ significantly between the study groups and the control group.

The genotype distribution of the NFKB1 (rs4648068) and RUNX2 (rs7771980) polymorphisms between the groups was analyzed (Tab. 2 and 3). For the NFKB1 rs4648068 polymorphism, no significant differences were observed between the genotypes in the individual groups. The GG genotype was slightly more frequent in the study groups than in the control group (osteoporosis $11.40 \%$, osteopenia $10.10 \%$ vs control group $8.20 \%, p>0.05$ ). In the case of rs 7771980 polymorphism of the RUNX2 gene in women with osteopenia, a higher frequency of TC heterozygotes was observed compared to the control group ( $29.40 \%$ vs $24.90 \%, p>0.05$ ), and in the group with osteoporosis the most common was the TT genotype $(78.70 \%$ vs $73.80 \%, p>0.05)$. There was no statistically significant difference between the distribution of genotypes of the studied polymorphism in the control and tested groups. No correlation was observed between genotype occurrence and osteoporosis development.

In addition, an analysis of the correlation between the NFKB1 rs464806 and RUNX2 rs7771980 polymorphisms with clinical parameters was performed (Tab. 4 and 5). The analysis did not show any statistical significance between the genotypic distribution and the individual clinical parameters analyzed. In the case of the NFKB1 polymorphism, lower BMI values were observed for patients with the $\mathrm{G}$ allele in the genotype in both osteopenia and osteoporosis. Patients with the GG genotype had a higher birth weight compared to the other genetic variants tested. It has been shown that women with the $\mathrm{G}$ allele in the osteoporosis group have lower bone mineral density values. It is suggested that the $\mathrm{G}$ allele in the genotype is associ-

\begin{tabular}{l}
$\begin{array}{l}\text { Table 2. The frequency of alleles and genotypes of NFKB1 polymorphism (rs4648068) in the group of women with osteopenia, osteoporosis } \\
\text { and in the control group }\end{array}$ \\
\hline
\end{tabular}

\begin{tabular}{l}
$\begin{array}{l}\text { Table 3. The frequency of alleles and genotypes of RUNX2 polymorphism (rs7771980) in the group of women with osteopenia, osteoporosis } \\
\text { and in the control group }\end{array}$ \\
\hline
\end{tabular}




\begin{tabular}{|c|c|c|c|}
\hline \multirow{2}{*}{ Genotype } & Mean \pm SEM & Mean \pm SEM & Mean \pm SEM \\
\hline & AA & AG & GG \\
\hline \multicolumn{4}{|l|}{ Controls } \\
\hline T-score & $-0.11 \pm 0.13$ & $0.13 \pm 0.19$ & $0.83 \pm 0.55$ \\
\hline Z-score & $0.51 \pm 0.28$ & $0.65 \pm 0.30$ & $1.17 \pm 0.76$ \\
\hline Body mass [kg] & $66.44 \pm 2.46$ & $69.83 \pm 2.08$ & $75.40 \pm 5.33$ \\
\hline BMI $\left[\mathrm{kg} / \mathrm{m}^{2}\right]$ & $25.34 \pm 0.83$ & $26.45 \pm 0.86$ & $27.33 \pm 2.41$ \\
\hline Birth weight [g] & $3587.50 \pm 255.26$ & $3.715 .00 \pm 70.10$ & $3510.00 \pm 141.77$ \\
\hline BMD L2-L4 [g/cm²] & $0.98 \pm 0.03$ & $0.96 \pm 0.04$ & $1.03 \pm 0.04$ \\
\hline BMD L2-L4 YA [\%] & $81.64 \pm 2.86$ & $80.15 \pm 2.90$ & $85.25 \pm 2.95$ \\
\hline BMD L2-L4 AM [\%] & $91.23 \pm 2.97$ & $89.30 \pm 3.39$ & $91.00 \pm 2.04$ \\
\hline \multicolumn{4}{|l|}{ Osteopenia } \\
\hline T-score & $-1.79 \pm 0.06$ & $-1.80 \pm 0.06$ & $-1.90 \pm 0.14$ \\
\hline Z-score & $-0.86 \pm 0.14$ & $-0.81 \pm 0.13$ & $-0.92 \pm 0.18$ \\
\hline Body mass [kg] & $66.71 \pm 1.94$ & $64.52 \pm 1.42$ & $64.36 \pm 1.88$ \\
\hline BMI $\left[\mathrm{kg} / \mathrm{m}^{2}\right]$ & $25.19 \pm 0.71$ & $24.27 \pm 0.49$ & $24.43 \pm 0.63$ \\
\hline Birth weight [g] & $3290.00 \pm 129.25$ & $3148.57 \pm 119.18$ & $3342.50 \pm 156.70$ \\
\hline BMD L2-L4 [g/cm²] & $0.93 \pm 0.04$ & $0.99 \pm 0.03$ & $0.99 \pm 0.04$ \\
\hline BMD L2-L4 YA [\%] & $77.82 \pm 3.45$ & $82.51 \pm 2.53$ & $82.50 \pm 3.01$ \\
\hline BMD L2-L4 AM [\%] & $86.33 \pm 3.62$ & $89.85 \pm 2.60$ & $92.00 \pm 3.95$ \\
\hline \multicolumn{4}{|l|}{ Osteoporosis } \\
\hline T-score & $-3.13 \pm 0.08$ & $-3.20 \pm 0.09$ & $-3.39 \pm 0.21$ \\
\hline Z-score & $-1.71 \pm 0.15$ & $-6.10 \pm 4.52$ & $-1.37 \pm 0.21$ \\
\hline Body mass [kg] & $62.58 \pm 1.43$ & $60.45 \pm 1.54$ & $57.57 \pm 2.72$ \\
\hline BMI $\left[\mathrm{kg} / \mathrm{m}^{2}\right]$ & $24.11 \pm 0.47$ & $23.52 \pm 0.54$ & $23.52 \pm 1.08$ \\
\hline Birth weight [g] & $3220.00 \pm 298.50$ & $3010.00 \pm 53.63$ & $3600.00 \pm 600.00$ \\
\hline BMD L2-L4 [g/cm²] & $1.02 \pm 0.03$ & $0.96 \pm 0.02$ & $0.92 \pm 0.02$ \\
\hline BMD L2-L4 YA [\%] & $84.80 \pm 2.35$ & $80.16 \pm 1.80$ & $76.33 \pm 2.00$ \\
\hline BMD L2-L4 AM [\%] & $93.14 \pm 2.39$ & $88.24 \pm 1.69$ & $85.87 \pm 2.28$ \\
\hline
\end{tabular}

Data are mean \pm SEM values. None of the parameters showed any significant difference among the genotypes; ${ }^{*} p$ value $<0.05$; SEM - standard error of the mean; $\mathrm{BMI}$ - body mass index; BMD — bone mineral density

ated with an increased risk of developing osteoporosis and may predispose to its development. For the RUNX2 polymorphism, no correlation between genotype and clinical parameter was observed.

\section{DISCUSSION}

Osteoporosis is a multifactorial disease associated with low bone mass and increased risk of fractures. However, the genetic factors may play a large role in its development. Despite ongoing research, little is known about the genetic mechanisms that control bone growth and formation. To thoroughly understand the molecular mechanisms, polymorphic variants of genes candidate for osteoporosis are still being sought [10]. In our study, the association of
NFKB1 rs4648068 and RUNX2 rs7771980 polymorphisms with osteoporosis was analyzed. Based on the frequency distribution of individual genotypes and alleles, an attempt was made to determine the genotype or allele predisposing to this disease.

Analyzing the $N F K B 1 \mathrm{~A}>\mathrm{G}$ polymorphism, a slightly more frequent occurrence of the GG genotype was observed in women with osteopenia and osteoporosis compared to control group with normal T-score (osteoporosis $11.40 \%$, osteopenia $10.10 \%$ vs control group $8.20 \%$ ). Patients with the $\mathrm{G}$ allele in the osteoporosis group showed lower bone mineral density values, suggesting that the $G$ allele is associated with an increased risk of developing osteoporosis. So far, the impact of the rs4648068 NFKB1 gene polymor- 
Table 5. Characteristics of the postmenopausal women with normal T-score, osteopenia and osteoporosis taking part in the study of the rs7771980 polymorphism of RUNX2 gene

\begin{tabular}{|c|c|c|c|}
\hline \multirow{2}{*}{ Genotype } & Mean \pm SEM & Mean \pm SEM & Mean \pm SEM \\
\hline & TT & TC & CC \\
\hline \multicolumn{4}{|l|}{ Controls } \\
\hline T-score & $0.04 \pm 0.14$ & $0.26 \pm 0.23$ & $-0.95 \pm 0.35$ \\
\hline Z-score & $0.46 \pm 0.26$ & $1.01 \pm 0.29$ & $-0.35 \pm 0.12$ \\
\hline Body mass [kg] & $66.80 \pm 1.52$ & $74.00 \pm 3.95$ & $76.00 \pm 3.86$ \\
\hline BMI $\left[\mathrm{kg} / \mathrm{m}^{2}\right]$ & $25.27 \pm 0.59$ & $27.95 \pm 1.40$ & $30.33 \pm 1.12$ \\
\hline Birth weight [g] & $3582.14 \pm 98.52$ & $3812.50 \pm 430.30$ & $3550.00 \pm 325.5$ \\
\hline BMD L2-L4 [g/cm²] & $0.97 \pm 0.03$ & $1.00 \pm 0.05$ & $0.79 \pm 0.04$ \\
\hline BMD L2-L4 YA [\%] & $80.82 \pm 2.23$ & $83.92 \pm 3.44$ & $66.50 \pm 2.45$ \\
\hline BMD L2-L4 AM [\%] & $90.70 \pm 2.27$ & $91.25 \pm 4.44$ & $69.40 \pm 3.12$ \\
\hline \multicolumn{4}{|l|}{ Osteopenia } \\
\hline T-score & $-1.81 \pm 0.05$ & $-1.80 \pm 0.08$ & - \\
\hline Z-score & $-0.88 \pm 0.09$ & $-0.74 \pm 0.21$ & - \\
\hline Body mass [kg] & $65.70 \pm 1.31$ & $64.75 \pm 1.87$ & - \\
\hline BMI $\left[\mathrm{kg} / \mathrm{m}^{2}\right]$ & $24.88 \pm 0.47$ & $24.18 \pm 0.66$ & - \\
\hline Birth weight [g] & $3189.52 \pm 75.98$ & $3338.57 \pm 219.35$ & - \\
\hline BMD L2-L4 [g/cm²] & $0.96 \pm 0.02$ & $0.97 \pm 0.06$ & - \\
\hline BMD L2-L4 YA [\%] & $79.94 \pm 1.67$ & $81.88 \pm 4.80$ & - \\
\hline BMD L2-L4 AM [\%] & $88.13 \pm 1.78$ & $89.62 \pm 4.95$ & - \\
\hline \multicolumn{4}{|l|}{ Osteoporosis } \\
\hline T-score & $-3.19 \pm 0.07$ & $-3.15 \pm 0.11$ & $-2.84 \pm 0.05$ \\
\hline Z-score & $-4.16 \pm 2.53$ & $-1.68 \pm 0.16$ & $-0.72 \pm 0.21$ \\
\hline Body mass [kg] & $61.23 \pm 1.16$ & $61.39 \pm 2.03$ & $57.50 \pm 2.45$ \\
\hline BMI $\left[\mathrm{kg} / \mathrm{m}^{2}\right]$ & $23.85 \pm 0.38$ & $23.71 \pm 0.74$ & $22.26 \pm 0.67$ \\
\hline Birth weight [g] & $3095.00 \pm 148.70$ & $3410.00 \pm 384.30$ & $3050.20 \pm 285.40$ \\
\hline BMD L2-L4 [g/cm²] & $0.97 \pm 0.02$ & $1.02 \pm 0.04$ & $0.98 \pm 0.14$ \\
\hline BMD L2-L4 YA [\%] & $80.53 \pm 1.40$ & $85.27 \pm 3.44$ & $81.67 \pm 11.70$ \\
\hline BMD L2-L4 AM [\%] & $89.11 \pm 1.42$ & $92.91 \pm 3.38$ & $91.00 \pm 8.74$ \\
\hline
\end{tabular}

Data are mean \pm SEM values. None of the parameters showed any significant difference among the genotypes; * $p$ value $<0.05$; SEM - standard error of the mean; $\mathrm{BMI}$ - body mass index; BMD — bone mineral density

phism in the Caucasian group on the development of osteoporosis has not been analyzed. The NFkB transcription factor and its effect on the skeletal system are still under investigation. It has been discovered that the deletion of the gene encoding NFKB in mice, more specifically the p50 (NFKB1) and p52 (NFKB2) subunits, is responsible for rare, hereditary osteopetrosis [11]. Therefore, our studies were undertaken to look for a new genetic marker that could differentiate patients with an increased predisposition to developing osteoporosis.

For the rs7771980 polymorphism of the RUNX2 gene, the TC genotype was more frequent in the osteopenia group compared to the control group, and the TT genotype was more common in the osteoporosis group. No correlation was observed between the genotype and the clinical parameters, which would indicate a predisposition to the development of osteoporosis. Bustamante et al. studied the effects of $-330 \mathrm{G}>\mathrm{T}$ polymorphism in promoter $\mathrm{P} 1$ and -1025 T>C polymorphism (rs7771980) in promoter P2 of RUNX2 in 821 Spanish postmenopausal women. The analysis showed that the $-330 \mathrm{G}>\mathrm{T}$ polymorphism was not associated with any of the phenotypes analyzed, and the -1025 T>C polymorphism was associated with bone mineral density in the femoral neck (FN BMD). Patients with TC genotype had higher mean corrected FN BMD values than patients with TT genotype. No relationship was found between the $-1025 \mathrm{~T}>\mathrm{C}$ polymorphism and bone mineral density in the lumbar spine (LS BMD). Due to the small size of the 
group with the CC genotype, no association with FN BMD was observed [12]. Lee et al. analyzed two RUNX2 polymorphisms: $-1492 \mathrm{~A}>\mathrm{T}$ and $-1025 \mathrm{~T}>\mathrm{C}$ among 729 Korean postmenopausal women. In this study, no significant relationship between the -1492 A>T polymorphism and BMD was found. The analysis showed a significant relationship between the CC genotype and the reduced bone mineral density in the lumbar spine and femoral neck compared to TC heterozygotes and TT homozygotes [13].

In another study, Pined's team investigated the effect of $-1025 \mathrm{~T}>$ C polymorphism (rs7771980) of the RUNX2 gene on the development of osteoporosis in 776 Spanish postmenopausal women. Like earlier researchers, they observed the relationship of polymorphism with BMD FN, but not with BMD LS. Women with the TC genotype had a higher BMD FN than women with the TT genotype. Unlike previous researchers, they found a relationship between CC genotype and higher BMD FN than women with TT genotype [14].

In addition, various researchers suggest that several other RUNX2 gene polymorphisms are associated with the development of osteoporosis. Auerkari et al. [10] studied the variability of $-330 \mathrm{G}>\mathrm{T}$ ( $r 559983488$ ) polymorphism in 180 Indonesian postmenopausal women. It has been shown that the TT genotype is associated with an increased risk of developing osteoporosis. Vaughan's team studied -336G > A polymorphism of the RUNX2 gene in 991 Scottish postmenopausal women. Their data suggest that RUNX2 alleles are associated with BMD in a manner dependent on menopause and body mass [16].

\section{CONSLUSIONS}

In conclusion, based on the literature data, no definite conclusions can be drawn. The NFKB1 gene rs 4648068 polymorphism has not yet been studied in connection with the development of osteoporosis. Our studies have shown that the $G$ allele in the genotype is associated with an increased risk of developing osteoporosis and may predispose to its development. Probably the RUNX2 gene rs7771980 polymorphism predisposes to the development of osteoporosis, but our studies have not confirmed this fact. Additional studies are required to confirm these relationships. All progress in this field has great potential, because understanding the mechanisms leading to the development of osteoporosis could allow the creation of effective therapies and the intro- duction of appropriate drugs. Early diagnosis of the disease and the implementation of appropriate treatment adapted to the genotype of patients can slow down or completely prevent its further development.

\section{Conflict of interest}

None.

\section{REFERENCES}

1. Sewerynek E, Stuss M. Obowiązujące wskazania do prewencji i leczenia osteoporozy pomenopauzalnej — choroby miliona złamań. Ginekologia i Perinatologia Praktyczna. 2016; 1(2): 45-55.

2. Janiszewska M, Kulik T, Dziedzic M, et al. Osteoporoza jako problem społeczny - patogeneza, objawy i czynniki ryzyka osteoporozy pomenopauzalnej. Probl Hig Epidemiol. 2015; 96(1): 106-114.

3. Doyle T, Kacmarynski K, Beckett E, et al. Osteoporosis Review. Primary Care Reports. 2019.

4. Boroń D, Plewka A, Jędrusik P. Polimorfizm -643C/T genu RANKL i jego związek z osteoporozą u kobiet po menopauzie. Ann Acad Med Siles. 2014; 68(6): 415-423.

5. Boyce BF, Xiu Y, Li J, et al. NF-KB-Mediated Regulation of Osteoclastogenesis. Endocrinol Metab (Seoul). 2015; 30(1): 35-44, doi: 10.3803/EnM.2015.30.1.35, indexed in Pubmed: 25827455.

6. Liu T, Zhang L, Joo D, et al. NF-KB signaling in inflammation. Signal Transduct Target Ther. 2017; 2, doi: 10.1038/sigtrans.2017.23, indexed in Pubmed: 29158945.

7. Zakłos-Szyda M, Budryn G, Grzelczyk J, et al. Evaluation of Isoflavones as Bone Resorption Inhibitors upon Interactions with Receptor Activator of Nuclear Factor-KB Ligand (RANKL). Molecules. 2020; 25(1), doi: 10.3390/molecules25010206, indexed in Pubmed: 31947859.

8. Witas HW, Wujcicka Wl. Genetyczne wyznaczniki osteoporozy. Postępy Biol Komórki. 2007; 34(3): 495-509.

9. Novack DV. Role of NF-kB in the skeleton. Cell Res. 2011; 21(1): 169-182, doi: 10.1038/cr.2010.159, indexed in Pubmed: 21079651.

10. Witkowska-Zimny M, Wróbel E, Przybylski J. Najważniejsze czynniki transkrypcyjne procesu osteoblastogenezy. Postępy Biol Komórki. 2009; 36(4): 695-705

11. lotsova V, Caamaño J, Loy J, et al. Osteopetrosis in mice lacking NF-kappaB1 and NF-kappaB2. Nat Med. 1997; 3(11): 1285-1289, doi: 10.1038/nm1197-1285, indexed in Pubmed: 9359707.

12. Bustamante $M$, Nogués $X$, Agueda L, et al. Promoter $2-1025$ T/C polymorphism in the RUNX2 gene is associated with femoral neck bmd in Spanish postmenopausal women. Calcif Tissue Int. 2007; 81(4): 327-332, doi: 10.1007/s00223-007-9069-2, indexed in Pubmed: 17878995.

13. Lee HJ, Koh JM, Hwang JY, et al. Association of a RUNX2 promoter polymorphism with bone mineral density in postmenopausal Korean women. CalcifTissue Int. 2009; 84(6): 439-445, doi: 10.1007/s00223009-9246-6, indexed in Pubmed: 19424741.

14. Pineda $B$, Hermenegildo $C$, Laporta $P$, et al. Common polymorphisms rather than rare genetic variants of the Runx2 gene are associated with femoral neck BMD in Spanish women. J Bone Miner Metab. 2010; 28(6): 696-705, doi: 10.1007/s00774-010-0183-2, indexed in Pubmed: 20407796.

15. Auerkari El, Suryandari DA, Umami SS, et al. Gene promoter polymorphism of RUNX2 and risk of osteoporosis in postmenopausal Indonesian women. SAGE Open Med. 2014; 2: 2050312114531571, doi: 10.1177/2050312114531571, indexed in Pubmed: 26770724.

16. Vaughan T, Reid DM, Morrison NA, et al. RUNX2 alleles associated with BMD in Scottish women; interaction of RUNX2 alleles with menopausal status and body mass index. Bone. 2004; 34(6): 1029-1036, doi: 10.1016/j. bone.2004.02.004, indexed in Pubmed: 15193550. 